\title{
Determinants of Negative Word-of-Mouth Communication using Social Networking Sites
}

\begin{abstract}
As customers now often turn to social media platforms to share their service experience, this study aims to examine the determinants of customers' negative word-of-mouth communication using social networking sites following a service failure. Although many studies have examined the electronic word-of-mouth communication, research focusing on negative word-of-mouth communication using social media platforms remain sparse. Building on the cognitive dissonance theory and social support theory, this study proposes and empirically examines the role of contextual, individual, and social networking factors in determining the customers' intentions to engage in negative word-of-mouth communication using social networking sites. Self-reported retrospective survey was used to obtain responses from 206 online shoppers. The results of the structural equation modeling showed that feeling of injustice, firm attribution, firm image, face-concern, reappraisal, use intensity, and tie strength are key antecedents of negative word-of-mouth communication. The findings provide valuable insights for managers in developing effective webcare interventions for negative word-of-mouth communication on social networking sites.
\end{abstract}

Keywords: Word-of-mouth, negative word-of-mouth, social networking sites, online shopping, service failure, social media. 


\section{Determinants of Negative Word-of-Mouth Communication using Social Networking Sites}

\section{Introduction}

The advent of social media has dramatically changed the way customers transmit word-of-mouth (WOM). Whereas customers previously shared experiences in person with a limited number of social contacts, social networking sites (SNS) now allow customers to share their experiences with a much larger audience (Lin, Fan, and Chau, 2014). As such, WOM influences the product and service choices of network members (Grégoire, Salle, and Tripp, 2014). In particular, negative word-of-mouth (NWOM) communication can adversely affect the attitudes and purchasing intentions of customers and potentially harm a firm's brand image. It can lead to undesirable long-term outcomes, such as brand dilution, volatility in stock returns, and the overall erosion of firm value (Bambauer-Sachse and Mangold, 2011; Verhagen, Nauta, and Feldberg, 2013). Moreover, competitors might exploit NWOM communication to damage a firm's reputation. Thus, when customer complaints go viral (i.e., shared on a massive scale on SNS) they can cause a public relations crisis for a firm (Daugherty and Hoffman, 2014; Grégoire, Salle, and Tripp, 2014). As most customers share positive experiences on SNS (Zhang, Feick, and Mittal, 2014), any NWOM transmitted on SNS can play a decisive role in customers' choice. Not surprisingly, practitioners and academicians have sought to understand what drives NWOM on SNS (Clark, 2013; Grégoire, Salle, and Tripp, 2014).

SNS have become a cultural phenomenon and a dominant mode of communication among young adults. These platforms facilitate interactions, foster collaboration, and promote community formation among users (Xu et al., 2012). More than 2 billion people, or about $29 \%$ of the world's population, use SNS (Kemp, 2015). Of these, Facebook alone has 936 million active users, Google+ has 300 million active users, and Twitter has 302 million active users (Ahmad, 2015). More than half of these users have submitted product reviews or have rated products on SNS (Roggio, 2011). Compared to the product information provided by marketers, customers consider user reviews to be less biased, more credible, and authentic and thus often rely on them when making purchasing decisions (Daugherty \& Hoffman, 2014). A recent survey indicated that $77 \%$ of online shoppers rely on user reviews to make purchasing decisions (Petersen, 2013). Baldacci 
(2013) reported that more than 1 million people read product or service reviews every week on a SNS platform such as Twitter, and more than $80 \%$ of these reviews are negative or critical. Considering the risks associated with negative reviews for a firm's sales and reputation, a clear understanding of the factors that motivate NWOM communication on SNS is critical for service managers to develop appropriate responses.

The present study aims to examine the determinants of NWOM on SNS. In response to a recent call for research (Chu and Kim, 2011; Eisingerich et al., 2015; Pfeffer, Zorbach, and Carley, 2014; Wolny and Mueller, 2013), we draw on cognitive dissonance theory (Festinger, 1957) and social support theory (Cohen and Wills, 1985) to understand the determinants of NWOM communication on SNS. The marketing literature emphasizes the role of contextual factors in NWOM communication (Sengupta, Balaji \& Krishnan, 2015; Yen, Gwinner, and Su, 2004). Other studies suggest that individual factors and social networking factors might have a similarly important role in WOM communication on social media (Alhidari, Iyer, and Paswan, 2015; Berry et al., 2014; Cheema and Kaikati, 2010; Son et al., 2012). Thus, we propose and empirically examine an integrated model of NWOM communication using SNS. Specifically, we examine the antecedent role of contextual, individual, and social networking factors in determining NWOM communication on SNS following an online service failure. We draw from the information system and marketing literature to examine the effects of perceived injustice, firm attribution, firm image, face-concern, emotion regulation, SNS use intensity, and the tie strength on consumers' intentions to engage in NWOM communication using SNS.

This research study makes two important contributions to the information systems literature. First, the majority of related studies focus on positive WOM (Lien and Cao, 2014; Ng, David, and Dagger, 2011). This study extends this by examining the determinants of NWOM using SNS. As many customers use social media platforms to share their negative service experiences (Clark, 2013), an examination of the determinants of NWOM communication on SNS will aid managers in better understanding the customer decision process. Moreover, this study addresses the recent call for research on WOM communication using social media platforms. Second, this study proposes that different factors motivate customers to transmit NWOM messages on SNS. While previous studies have shown the influential role of situational factors in 
determining NWOM behaviour, we argue that they are limited in their ability to fully explain NWOM behaviour on social media. This is because situational factors can only explain the conditional nature of the relationship and not the static or the long-term characteristics that may determine NWOM behaviour. Consequently, this study considers the influence of contextual, individual, and social networking factors on customer intentions to transmit NWOM messages on SNS. By considering different factors, this study broadens our understanding of NWOM communication.

In the next section, we present the theoretical development process and hypotheses based on the cognitive dissonance theory and social support theory. In subsequent sections, we discuss the methodology and analyses, and then conclude with the implications of our findings.

\section{Theoretical Background}

\subsection{Negative word-of-mouth communication}

A NWOM communication is defined as a customer's effort to share negative or unfavourable feedback or opinions with friends, family, and others. The dissemination of NWOM on SNS constitutes a new form of electronic WOM communication (eWOM). Transmitting NWOM messages is a social activity, as customers share their opinions and experiences with other network members through comments and discussions. When a customer transmits NWOM messages on SNS, he or she is likely to consider the potential benefits and costs first. Prior research suggests that transmitting NWOM messages on SNS can place customers under the scrutiny and judgement of other network members, who form impressions based on the expressed opinions or experiences (Eisingerich et al., 2015). Although WOM communication on social media (sWOM) is similar to face-to-face WOM and eWOM, it differs significantly in terms of anonymity, social risk, confidentiality, and geographical and spatial freedom. In face-to-face WOM communication, people are in close contact with others and draw on social and contextual cues, such as non-verbal communication, voice intonation, posture, etc. (Verhagen, Nauta, and Feldberg, 2013). In contrast, sWOM usually involves non-simultaneous conversations with a network of people (see Table 1 for the differences in WOM, eWOM, and sWOM communications). 
Cheung and Lee (2012) suggested that the socially extensive SNS environment provides network members with greater opportunities to share their product or service experiences. Moreover, by associating with products or services through their reviews, customers use as a tool for self-expression and for enhancing their ability to give advice and recommendations to network members. These factors encourage the development of sWOM (Grégoire, Salle, and Tripp, 2014). As SNS have few geographical and temporal constraints, NWOM communication has the potential to reach a wide audience of people with a shared interest in the product or service. Furthermore, as firms have limited control over customer interactions on social media, NWOM can quickly spread and adversely affect a firm's reputation and future business. Therefore, an examination of the determinants of NWOM communication on SNS is essential for marketers seeking to develop effective webcare interventions.

\section{[Insert Table 1 about here]}

Prior studies suggest that NWOM can adversely impact customer and public perceptions of a product and firm (Bambauer-Sachse and Mangold, 2011; Verhagen, Nauta, and Feldberg, 2013). Despite the significance of NWOM behaviour on SNS, there has been limited focus on understanding its determinants. The few studies that have addressed the antecedents of NWOM communication have done so in the context of traditional or online channels (Hennig-Thurau et al., 2004; Cheung and Thadani, 2012). In the context of social media platforms, some qualitative studies have addressed how firms respond to NWOM communication (Van Noort and Willemsen, 2012; Clark, 2013; Grégoire, Salle, and Tripp, 2014); however, little systematic research exists on the drivers of NWOM communications beyond customer dissatisfaction with service encounters. Table 2 presents an overview of the research on NWOM through online platforms.

\section{[Insert Table 2 about here]}

As seen in Table 2, most studies have addressed NWOM communications from the receiver's perspective (Ba and Pavlou 2002; Zhang, Craciun, and Shin, 2010; Yoo, Kim, and Sanders, 2015), with only a few addressing the generation of NWOM communications. This highlights a need to examine NWOM communication from the sender's perspective to advance our knowledge in this area, and, in particular, to understand the determinants of NWOM communications on SNS. The few studies that have 
addressed NWOM from the sender's perspective have largely investigated the role of contextual factors (Ward and Ostrom, 2006). Thus, there is a clear need to consider other factors when explaining NWOM communications. Furthermore, he prior studies have examined the NWOM communications in online opinion platforms and blogs (Bambauer-Sachse and Mangold, 2013; Vermeulen and Seegers, 2008). Given the increasing popularity of social media, it would be of interest to examine NWOM communications on SNS. Moreover, as WOM communications can reach a large number of network members on SNS (Wolny and Mueller, 2013), an examination of the determinants of NWOM communication using SNS may aid managers in developing effective webcare strategies. In addressing the above gaps, the present study uses cognitive dissonance and social support theories as the theoretical basis for understanding the role of contextual, individual, and social networking determinants of NWOM on SNS following a service failure.

\subsection{Cognitive dissonance theory}

The theory of cognitive dissonance developed by Festinger (1957) has been widely used in the literature to justify the decisions customers make following a negative experience. The basic premise of cognitive dissonance theory is that a discrepancy between product expectations and performance cause dissonance or imbalance in the customer's cognitive system. Customers reduce this cognitive dissonance through attitude change, self-affirmation, trivializing the importance of cognition, and by disseminating WOM ( $\mathrm{Ng}$, David, and Dagger, 2011). While the theory of cognitive dissonance suggests that individuals can experience dissonance after obtaining new information or post-decision, this study considers the later form of dissonance as the central construct here is NWOM communications that customers engage in following a service failure encounter. When product or service performance falls short of the expectations, customers experience disconfirmation and dissonance (Festinger, 1957). In such situations, they may engage in NWOM communications to reduce their cognitive dissonance. Moreover, communicating their negative experiences allows them to convince others of their decision. With this in mind, the cognitive dissonance theory is used in this study as a theoretical framework for examining the determinants of NWOM communications using SNS. 


\subsection{Social support theory}

The social support theory focuses on the social support individuals rely on and give in a social network to cope with negative events (Cohen and Wills, 1985). According to this theory, social support is an important interpersonal resource that aids an individual in coping with stress. An individual's perception of the availability of social support is more important in determining coping effectiveness than the actual social support he or she receives. Perceived social support serves as a protective layer for individuals during stressful events and helps them maintain their well-being (Cutrona and Russell, 1987). The extant literature suggests that individuals obtain social support through three characteristics of the social network: the structure of the social network, such as size; beliefs about the members regarding their support in positive as well as negative events; and the behavioural actions that members provide for social support. These factors determine the likelihood of an individual to rely on a social network for social support.

Based on the premises of the social support theory, we contend that the perceived social support individuals receive from the social connections in their network may determine their intentions to transmit NWOM communications using SNS. As negative service experiences are stressful events, individuals may share their negative messages on SNS to obtain emotional and information support from the network members (Chung and Buhalis, 2008). While previous studies have shown that social support on SNS influence an individual's well-being, life satisfaction, and social commerce adoption (Liang et al., 2011), this study extends this to understand the role of social support in NWOM communications using SNS.

This study integrates the theories of cognitive dissonance and social support, and bridges the service failure literature to the social support literature in examining the determinants of NWOM communication using SNS. As customers experience disconfirmation or discrepancies during service failures, the cognitive dissonance theory is used to explain their response choices (Festinger, 1957). Specifically, the perceived extent of disconfirmation may affect a customer's intentions to engage in NWOM communications. We argue that as situational factors influence customer expectations of service performance (Day, 1977), cognitive dissonance theory may determine how customer's react to disconfirmation. Similarly, as personal abilities account for the inter-personal differences in disconfirmation perceptions, we contend that cognitive 
dissonance theory may help in understanding the role of individual determinants of NWOM communications. However, the recent emergence of SNS has enabled people to receive social support from others. Indeed, social support is the major social resource or value that people obtain from SNS (Liang et al., 2011). As social support exerts protective effects against stress and anxiety (Cohen and Wills, 1985), we extend this argument to propose that social support on SNS may determine how customers react to service failure. Specifically, the extent of the social support that customers derive from their social network may determine the likelihood of NWOM communications on SNS. Thus, the social support theory complements the cognitive dissonance theory in understanding the role of contextual, individual, and social networking determinants in NWOM communication using SNS.

\section{Research model and hypotheses}

This study considered contextual, individual, and social networking factors as determinants of NWOM communication using SNS. We considered three contextual factors that could influence NWOM communications: feelings of injustice, firm attribution, and firm image. These contextual factors have considerable theoretical interest and practical importance in explaining NWOM communications. When individuals perceive unfairness or injustice in an exchange, they attempt to limit the loss through various actions, including the dissemination of NWOM communications. Moreover, customers will try to make sense of what has happened during the failed service encounter by engaging in the attribution process (Weiner, 1985). Advocates of a process approach argue that injustice is a necessary but not sufficient condition to explain NWOM behaviour. Consequently, feeling of injustice, firm attribution, and firm image are considered as key contextual determinants of NWOM communications on SNS. Examination of these determinants allows a clear understanding of the NWOM communication process on SNS in general.

Among individual factors, face-concern and emotion regulation are key antecedents of NWOM intentions. Face concern is the favourable social self-worth that individuals desire others to have of them (Lee, Sparks, and Butcher, 2013). Studies show that consumers with high face concern are apprehensive of the opinions of others and perceive high social and psychological risks. As SNS represent social connections among network members, individual differences in face concern may influence NWOM 
communications on SNS. Emotion regulation relates to the process by which individuals regulate their emotions to attain desired adaptive outcomes (Gross and John, 2003). It affects social interactions by either regulating the situation or by changing the individual's physiological or observable signs of emotion. As salient emotions may influence social interactions, it is postulated that the customer's emotion regulation plays a key role in NWOM behaviour on SNS.

In this study, SNS use intensity and tie strength are considered as social networking determinants of NWOM communications. Prior studies suggest that increased usage and number of friends on SNS may affect interpersonal communication among network members (Tufekci and Wilson, 2012). In spite of this, little research exists on the influence of SNS use intensity on WOM communication. As the use of SNS facilitates interaction and connectedness with others, we propose that the use intensity of SNS affects NWOM communications. Furthermore, the strength of ties an individual has with the network members on SNS may stimulate social exchanges (Zhao et al., 2012) and lead to increased WOM communication. Thus, the social networking determinants considered in this study may have a significant influence on NWOM communications on SNS. Figure 1 presents the conceptual framework of the study.

[Insert Figure 1 about here]

\subsection{Contextual determinants}

\subsubsection{Feeling of injustice}

Feeling of injustice refers to the extent to which the service outcome and/or process is seen by customers as unacceptable, unequal, and unfair. The cognitive dissonance theory suggests that customers are likely to experience cognitive dissonance in a failed service encounter ( $\mathrm{Ng}$, David, and Dagger, 2011). The service failure encounter violates the psychological contract and norms of the customer-company relationship. In such cases, customers perceive betrayal and may engage in NWOM communication to vent their dissatisfaction, frustration, or to seek revenge. Richins (1983), Weun, Beatty, and Jones (2004) and Balaji and Sarkar (2013) provide empirical evidence for the relationship between feeling of injustice and NWOM communications. It was reported that as problem severity increases customers tend to expend a great deal of effort in responding to the dissatisfaction, which leads to NWOM communication. Based on the above 
considerations, we propose that as the perceived injustice of a service encounter increases, consumers are more likely to use SNS to transmit NWOM communications. This is because the availability of a large number of network participants on SNS allows customers to obtain timely information, seek advice, and obtain problem solving assistance. They can also seek solace and empathy for the injustice and promote collective action against the service provider. As sharing negative experiences on SNS provides customers with cognitive clarity and projects their self-image, we propose that:

$\mathbf{H}_{\mathbf{1}}$ : The feeling of injustice has a positive influence on NWOM communications using SNS.

\subsubsection{Firm attribution}

Firm attribution refers to the extent a customer believes that the firm's efforts or behaviour is responsible for the failed service encounter. From the cognitive dissonance perspective, firm attribution increases the expectation that the service failure will be fairly resolved by the firm. Subsequently, they will experience lower cognitive discomfort or dissonance and less inclination toward NWOM communications (Yen, Gwinner, and Su, 2004). Zhu et al. (2013) suggests that the assignment of blame on the firm intensifies the belief of customers that it is the firm's responsibility to remedy or rectify the problem. In doing so, expectations of a favourable service outcome increase. In such cases, customers are less likely to experience negative emotions and more likely to engage in complaint behaviour to the firm while eschewing NWOM communication (Richins, 1983). Kim et al. (2003) found that when customers attributed the locus of responsibility for a failed encounter to the firm, they were more likely to perceive greater value in complaining directly to the firm. Thus, we propose that customers are less likely to engage in NWOM communications using SNS when the firm is perceived as responsible for the negative experience and subsequently more open to providing timely and fair redressal. Thus, the attribution of service failure to the firm results in fewer NWOM communication instances using SNS. Therefore, it is proposed that:

$\mathbf{H}_{2}$ : Firm attribution has a negative influence on NWOM communications using SNS.

\subsubsection{Firm image}

Perceived firm image (firm reputation) reflects an overall evaluation of the service provider based on both direct and indirect experiences. It is argued that global firm evaluations often dominate customer 
evaluations of service encounters as they can overcome or suppress the negative emotions of a service failure encounter. For example, Hess (2008) showed that an excellent reputation provides a protective layer that shields a firm from the negative consequences of service failure. Likewise, Liao and Cheng (2013) demonstrated that high equity brands suffer less from the adverse effects of self-service innovation failures. The authors reported that customers exhibit a larger zone of tolerance for failures in high equity brands and this leads to lower dissatisfaction. More recently, Sengupta, Balaji, \& Krishnan (2015) show that firm image provides cues for the customers that the service failure is an aberration and this may result in positive behavioural intentions towards the service provider. Thus, it can be argued that for service providers with favourable global evaluations, customers might experience lower cognitive dissonance or discomfort. This may lead to reduced intentions to engage in NWOM communications using SNS following a negative service experience. Therefore, it is proposed that:

$\mathbf{H}_{3}$ : Firm image has a negative influence on NWOM communications using SNS.

\subsection{Individual determinants}

\subsubsection{Face concern}

Face concern or consciousness refers to the projection of self-image or self-worth to others in a relational context. The concept of face is not new and is widely discussed in the social psychology literature. For instance, Sun (2014) found that face-consciousness is positively related to perceived risk. It was argued that individuals with strong face-concern hold high social needs and pay greater attention to the extrinsic cues of a product. Thus, they are likely to pay more and choose a highly reputed brand to prevent loss of face with other people (Lee, Sparks, and Butcher, 2013). In situations of conflict, consumers with strong faceconcern are likely to use dominating facework strategies such as defending, expressing emotions, and aggressive behaviour. Dominating facework strategies help them present a reliable image to others and communicate their desire to win a conflict. While the role of the face in the information systems literature is limited, recent studies reveal that face-concern relates to online consumption behaviours (Henderson et al., 2013). From the cognitive dissonance perspective, it can be argued that high face-concern individuals 
experience greater cognitive dissonance from the threat of loss of face (Sun, 2014) and thus use NWOM communications on social media platforms as a face maintaining strategy. Therefore, it is proposed that:

H4: Face-concern has a positive influence on NWOM communications using SNS.

\subsubsection{Emotion regulation}

Gross (2002, p. 282) defines emotion regulation as the "processes by which we influence which emotions we have, when we have them, and how we experience and express them." While it is generally agreed that emotions emanate when something important is at risk, recently it is has been appreciated that individuals regulate their emotions so that they can better serve their goals. This process by which individuals control and modify their emotions in order to attain desired states is referred to as emotion regulation (Gross, 2002). At the broadest level, people can regulate their emotions either by changing the appraisal of the external stimulus or by altering the internal emotional cues that trigger the behavioural responses (Gross and John, 2003). The former refers to reappraisal, and is an antecedent-focused regulation strategy that occurs before responses are generated. The latter is called suppression emotion regulation and occurs after responses are generated (Gross, 2002). Gross and John (2003) indicated that while suppression involves conscious restraint of the emotional expression, reappraisal encompasses re-evaluating the stimulus by changing thoughts or behaviours.

Previous studies show that suppression is related to depression, anxiety, and reduced positive affect. It decreases the expression of emotions, but does not influence the subjective feeling of the emotions. In contrast, reappraisal decreases both expression and experience of emotions (Ehring et al., 2010). Moreover, it is associated with increased life satisfaction, less negative affect, less depression, and lessened anxiety (Moore, Zoellner, and Mollenholt, 2008). Thus, individuals who use reappraisal emotion regulation are less

likely to share their emotional experiences with others as they experience lower negative feelings following the reassessment of the stimuli. In other words, reappraisal reduces the cognitive dissonance by reinterpreting the service failure encounter. However, individuals using suppression emotion regulation may openly share their emotional experiences with others, as they feel apprehensive and stressed about their experience. In this study, we argue that emotion regulation differences affect NWOM communications 
on SNS. It is posited that when customers experience a service failure, they would evaluate the appropriateness of negative emotions based on the situation. When suppression is used, customers may regulate or suppress their negative emotions to the point that they do not express dissatisfaction to the service provider. However, as the emotions are not totally eliminated, they may express their negative emotions indirectly to others in the form of retaliatory behaviours like NWOM through SNS. Therefore, it is proposed that:

$\mathbf{H}_{5 \mathbf{a}}$ : Suppression emotion regulation has a positive influence on NWOM communications using SNS.

$\mathbf{H}_{5 \mathbf{b}}$ : Reappraisal emotion regulation has a negative influence on NWOM communications using SNS

\subsection{Social network determinants}

\subsubsection{SNS use intensity}

SNS use intensity refers to the extent to which a SNS is integrated into the daily routines of a customer (Brown, Broderick, and Lee, 2007). It seems logical that those who actively use SNS are familiar with and skilled at using it effectively for spreading NWOM communication. According to Zajonc (1980), continuous exposure tends to increase an individual's attitude or liking towards a specific medium. The mere exposure effect resulting from the frequent use may increase the overall use of SNS. For example, Sun and Zhang (2006) demonstrated that internet use is positively related to online opinion leadership and online opinion seeking. The study findings revealed that individuals with high levels of internet use exhibited an increased desire to share information about products or services with others. Cha (2009) found that experience with SNS is positively associated with internet purchase behaviour. Consequently, SNS use intensity is considered a potential determinant of NWOM communications on SNS. The social support theory predicts that the size and structure of a social network determines the intention to seek support or give social support within the networked community (Tufekci and Wilson, 2012). Thus, it is plausible that customers who actively use SNS may be more likely to engage in NWOM communications to express their discontent following a service failure. Therefore, it is proposed that:

H6: SNS use intensity has a positive influence on NWOM communications using SNS. 


\subsubsection{Tie Strength}

In social support theory, tie strength ${ }^{1}$ is related to the closeness of an individual's relationship with other members on the SNS. The tie strength among the members on SNS can vary from strong to weak depending on the nature of exchanges. Strong ties are characterized by common norms, open and frequent communication, trust and emotional closeness, expressive and instrumental exchanges, long-term reciprocity, and the maintenance of close relationships (Chu and Kim, 2011; Zhao et al., 2012). Extant studies on social networks have shown that tie strength affects information flow. For example, Brown and Reingen (1987) demonstrated that information from strong tie sources is more likely to affect the receiver's decision making than those from weak tie sources. It was argued that the perceived credibility of the strong tie sources affects the referral behaviour during information seeking and WOM. In addition, individuals with strong ties spend more time talking about their present product or service experiences, as they know each other well. In contrast, weak ties tend to spend time on discussing older experiences to learn more about each other and to find common interests. Thus, strong tie individuals are more likely to engage in WOM communication than weak ties (Zhao et al., 2012).

Pan and Chiou (2011) illustrated that negative information was perceived as more trustworthy when it was posted by net pals with whom the receiver had stronger, rather than weaker, ties. It was argued that as an information seeker, strong ties act as a signal or cue for the credence of the online information. Based on the above, we propose that when customers experience service failure, customers with strong ties with other network members are more likely to engage in NWOM behaviour using SNS as other members consider them more credible. Additionally, the positive feelings towards other members in strong tie

\footnotetext{
${ }^{1}$ Note that tie strength and trust are distinct constructs. While trust is defined narrowly as the expectation that the other party does not engage in an opportunistic behaviour (Moorman, Deshpande, and Zaltman, 1993), tie strength, to the contrary is a much broader concept that describes the way, means, and expressions of communication, and motivations of communication between parties (Chu and Kim, 2011). Tie strength derives from the intimacy, reciprocity, and cohesiveness that exists between the parties (Granovetter, 1973). Since trust is an essential element of communication it paves the way for collaborative dialogue between parties which is likely to result in improved social ties and relational closeness between exchange partners.
} 
relationships make customers use SNS for advising and helping others in their decision-making process. Therefore, it is proposed that:

$\mathbf{H}_{7}$ : Tie strength has a positive influence on NWOM communications using SNS.

\section{Study design and research method}

\subsection{Procedure}

The study participants were actual online shopping customers with a recent negative experience. Two reasons motivated the choice of online shopping as the focus of this study. First, there are a growing number of complaints by customers about service failures during online shopping (Smyth, 2015). Second, online shopping is characterized by low switching costs and customers can easily switch online retailers when they experience a service failure (Kuo, Yen, and Chen, 2011). Thus, it provides a suitable setting to examine customer responses to service failure experiences.

Study participants were asked to reflect on their most recent negative experience (in the past 3 months) with online shopping and fill out a survey questionnaire. The retrospective self-report approach was consistent with prior studies on service failure in the online context (Mattila and Cho, 2011). Moreover, this strategy avoids bias in the data collection process as it ensures that all participants are consistent in their reflection of the negative experience across the defined constructs used in this study.

The chain referral sampling method was used to recruit participants for this study. An initial set of seed respondents who met the study criteria (e.g. a recent negative experience in online shopping and an active user of a SNS) was recruited through SNS and these participants were asked to recommend other potential participants. The process was repeated iteratively till the target sample size was reached. The chain referral sampling method reached qualified respondents through social connections and interpersonal relations. As multiple referrals can be made, this sampling method can quickly overcome participant recruitment difficulties (Baltar and Brunet, 2012). Furthermore, a more representative sample can be recruited through chain referral method.

The self-administered online questionnaire had three sections. The first section was designed to collect demographic information. The second section of the questionnaire focused on the respondents' recent 
service failure experience in the online shopping context. Open-ended and close-ended questions were used to obtain information on the recent negative online shopping experience. The final section of the questionnaire comprised of 31 statements related to NWOM communication and its antecedents, and the respondents were asked to evaluate them based on their recent negative online shopping experience.

\subsection{Measures}

Existing scales operationalized on 7-point Likert scales ranging from 'strongly disagree' to 'strongly agree' or semantic differential scales were used. The feeling of injustice was operationalized with three Likert scale items taken from Weun, Beatty, and Jones (2004). Firm attribution was measured using two items adapted from Zhu et al. (2013). Perceived firm image had three indicators adopted from Veloutsou and Moutinho (2009) to reflect the overall reputation of the service provider. Face concern was measured with six items reflecting the positive image of the self (Wan, 2013). To measure the emotion regulation an existing scale by Gross and John (2003) was adopted. The suppression and reappraisal dimensions of emotion regulation were measured using six items that reflected the regulation of negative emotions relevant to the present study. SNS use intensity was measured using six Likert scale items adopted from Valenzuela et al. (2009). Tie strength ${ }^{2}$ was operationalized using four items taken from Wang, Yu, and Wei (2012). NWOM communication using SNS was measured using three semantic differential items modified from Wan (2013).

\subsection{Content validity}

Before administration of the online questionnaire for data collection, the initial instrument was pretested with 30 online shoppers. The pre-test participants provided feedback on wording, clarity, content, and the structure of the survey instrument. Based on this feedback, the phrasing of some items was modified and minor changes made to the questionnaire format. This improved the readability of the questions and helped

\footnotetext{
${ }^{2}$ Note that this study collected subjective tie strength perceptions through the survey questionnaire. The respondents rated relationship strengths with network members on a four-item tie strength scale. This study did not collect objective tie strength information from participant profiles and their interaction records.
} 
to establish the content validity of the survey instrument. Furthering this aim, reliability and validity tests on the study constructs provided support for the questionnaire.

\subsection{Sample}

Two hundred and six usable responses were obtained for the study. As a sample size of 200 is generally recommended for structural equation modeling (Hoelter, 1983), our sample size was determined to be sufficient. This sample size is comparable to prior studies on WOM communication (Jeong and Jang, 2011: sample size $=201$; Luo et al., 2013: sample size $=199$ ). In addition, prior to data collection, we used G*Power 3.0 (Faul et al., 2007) to compute the required sample size. The sample size of our hypothesized model with a medium effect size of $1-\beta=0.95$ and $\alpha=0.05$ should be at least 89 . Thus, 206 responses was sufficient for detecting a medium effect size.

About 57 percent of the respondents were male and 43 percent were female. The majority of the respondents (62 percent) were aged between 31 and 40 years of age. Some 83 percent of the respondents had graduate degree or above in education. While all respondents had membership in at least one SNS, the most popular social media platforms were Facebook (98 percent), Twitter (70 percent), Hangout (31 percent), and LinkedIn (18 percent). A majority of respondents (91 percent) indicated that they had read negative service-related messages on SNS. More than half of the respondents (57 percent) reported posting a negative product or service opinion on a SNS. A content analysis of the open-ended question performed by two of the authors revealed that delivery issues were the most common service failure experiences in online shopping (53 percent). Poor customer service (24 percent), payment problems (9 percent), and website issues ( 8 percent) were some of the other online service failures experienced by the respondents in this study.

\subsection{Common method bias}

As the data was collected through a self-reported questionnaire, common method bias (CMB) was a concern as it could bias the estimates of the relationships among the study constructs. Both procedural and statistical remedies, as recommended by Podsakoff et al. (2003) were used to control CMB. Procedurally, the respondents' were assured of anonymity and that there were no right or wrong answers. Different 
response formats were used for the measurement of constructs. For instance, NWOM communication was measured using a semantic differential scale format, while others were measured using Likert-scale formats. Well-established measures were used to reduce ambiguity and the items were counterbalanced to control priming effects.

The statistical remedies included Harman's single-factor test to assess the presence of CMB (Podsakoff et al., 2003). The results of the exploratory factor analysis for all items in this study, using principle component factor analysis, did not reveal a dominant factor. In all, the nine factors accounted for 80 percent of the variance, with the first factor contributing 16 percent of the variance. The results indicated that 31 indicators manifested on one factor did not represent the majority of the variance. Thus, CMB was not likely to affect the results (Podsakoff et al., 2003). We used another approach by Lindell and Whitney (2001) to validate the above findings. The marker variable approach as recommended by Lindell and Whitney (2001) was used to compute the common bias method adjusted correlation matrix. As the pattern of correlations remained same after adjustment, we concluded that common method bias is unlikely to be of concern in this study.

\section{Results and findings}

Structural equation modeling (SEM) using the Analysis of Moment Structures (AMOS) 20.0 was used to analyse the data. The two-step approach proposed by Anderson and Gerbing (1988) was used to assess the measurement model prior to the estimation of the structural model. While the measurement model provided an assessment of the validity and reliability of the study constructs, the structural model assessed the causal relationships among the constructs.

\subsection{Measurement model}

Confirmatory factor analysis (CFA) was conducted and the measurement models derived from the literature were feeling of injustice, firm attribution, perceived firm image, face concern, suppression, reappraisal, SNS use intensity, tie strength, and NWOM. These measurement models were all tested for model fit. The goodness of fit index used to test for the absolute model fit were chi-square $\left(\chi^{2}\right)$, degrees of freedom (df), p-value, and root mean square error of approximation (RMSEA). The acceptable RMSEA 
threshold values were 0.08 or below (Hair et al., 2009). In testing the incremental model fit indices, incremental fit index (IFI), tucker-lewis fit index (TFI), and comparative fit index (CFI) were used, with acceptable threshold values of 0.90 and above (Hair et al., 2009). Finally, the normed model fit $\left(\chi^{2} / \mathrm{df}\right)$ test was used to examine the parsimony fit of the model, with acceptable threshold values between 1 and 2 (Hair et al., 2009). The results of the overall CFA indicated a good model fit to the data with $\chi^{2}=458.20, \mathrm{df}=$ 393, $\mathrm{p}$-value $=0.013, \mathrm{RMSEA}=0.028, \mathrm{IFI}=0.983, \mathrm{TLI}=0.979, \mathrm{CFI}=0.983$ and $\chi^{2} / \mathrm{df}=1.166$.

\subsection{Reliability and validity}

The measurement models were tested for convergent and discriminant validity. Table 3 shows the indicators of each measurement model and their respective standardized regression weights $(\lambda)$. All $\lambda$ were significant at 0.05 significance level and ranged from 0.58 to 0.93 . The results in Table 3 show that all measurement models met the necessary thresholds of Cronbach's alpha $(\alpha)$ of 0.7 and above, composite reliability ( $\rho$ ) of 0.7 and above, and average variance extracted (AVE) of 0.5 and above (Fornell and Larcker, 1981). This indicated that the measurement models were internally consistency and the instrument used was measuring the constructs in a meaningful way. Additionally, the AVE of each measurement model was above 0.5, implying that they have convergent validity (Hair et al., 2009).

\section{[Insert Table 3 about here]}

Discriminant validity was then assessed on each measurement model. Using the Fornell and Larcker (1981) approach, discriminant validity is achieved when the square root AVE of the construct is greater than the correlations $(\phi)$ between the respective constructs. For example, the $\phi$ between feeling of injustice (FI) and negative word-of-mouth (NWOM) was 0.28, while the square-roots of AVE for FI and NWOM were 0.87 and 0.91 respectively. Therefore, as the square-rooted AVE for both FI (0.87) and NWOM (0.91)

were greater than the $\phi$ between these constructs, discriminant validity was supported. All constructs had discriminant validity, as shown in Table 4.

[Insert Table 4 about here] 


\subsection{Structural model}

The SEM was conducted using maximum likelihood estimation with the sample size of 206. A bootstrapping approach was used with 5000 resamples. The results show that the exogenous constructs explained 31 percent of the total variance in NWOM communications using SNS. The hypotheses were then tested and the results presented in figure 2 .

[Insert figure 2 about here]

Figure 2 shows that feeling of injustice was positively related to NWOM using SNS $(\beta=0.21, p<0.01)$, supporting $\mathrm{H}_{1}$. Firm attribution had a negative impact on the intention to engage in NWOM communications using SNS $\left((\beta=-0.17, p<0.05)\right.$. This supported $\mathrm{H}_{2}$. Support for $\mathrm{H}_{3}$ was found as perceived firm image was negatively associated with NWOM intentions on SNS $(\beta=-0.18, p<0.01)$. Face-concern was positively related to NWOM intentions, such that strong face-concern individuals reported greater intentions to engage in NWOM using SNS $(\beta=0.21, p<0.01)$. Thus, $\mathrm{H}_{4}$ was supported. Regarding emotion regulation, reappraisal $(\beta=-0.17, p<0.05)$ was found to be negatively related to NWOM communications using SNS. This provides support for $\mathrm{H}_{5 \mathrm{~b}}$. However, suppression emotion regulation did not influence NWOM communications on SNS as hypothesized $(\beta=0.05, p=0.53)$, so $\mathrm{H}_{5 a}$ was not supported. $\mathrm{H}_{6}$ was supported as SNS use intensity was positively related to NWOM intentions on SNS $(\beta=0.20, p<0.01)$. Similarly, Tie strength among the peers on SNS was found to be positively associated with NWOM intentions $(\beta=0.16, p<0.05)$, supporting $\mathrm{H}_{7}$.

\subsection{Post-hoc analysis}

As the surveyed respondents included both those who had prior experience sharing their negative experiences on SNS and those who had not shared their service failure experiences on SNS, this study post hoc tested for a difference in the antecedents of NWOM between the two groups. Of the 206 respondents in our sample, 117 respondents (57 percent) had prior experience with posting negative experiences on a SNS, while 89 respondents (43 percent) had not shared a negative experience on a SNS. Thus, the hypotheses were tested separately for these two groups (no experience and experience). The approach of Fornell and Larcker (1981) was used to statistically compare the corresponding path coefficients for the 
two groups and compute t-values. Table 5 presents the differences in the path coefficients between the two groups.

[Insert table 5 about here]

The results showed a significant difference between the two groups of respondents. Experienced customers paid attention to face concern and tie strength, while respondents with no prior experience gave more importance to reappraisal emotion regulation in their intentions to engage in NWOM communications on SNS. In the context of our study, tie strength was found to be a significant determinant of NWOM communication for participants with prior WOM communication experience. This finding is consistent with the literature that suggested a strong relationship between tie strength and WOM communication ( $\mathrm{Li}$ and $\mathrm{Du}, 2011)$. It can be argued that as individuals are more likely to rely on trusted acquaintances, family members, and friends with whom they maintain strong ties for emotional support and advice, experienced customers with strong ties are more likely to engage in NWOM communication using SNS following a service failure.

Similarly, the face concern of experienced customers was found to have a negative influence on NWOM communication. This suggests that experienced customers are less concerned about their image or presentation when sharing NWOM communications with their friends, acquaintances, and others on SNS. As face derives from social relationships with others (Lee, Sparks, and Butcher, 2013), it can be argued that experienced customers would have established their self-image through previous social interactions on SNS. Finally, reappraisal emotion regulation was found to significantly reduce the likelihood of NWOM communication on SNS for respondents without any prior experience, more so than for experienced users. Emotion regulation is an important mechanism for goal attainment (Gross, 2002). The results show that respondents without prior experience were more likely to re-evaluate the negative experience and this may tend to reduce their intentions to engage in NWOM communications using SNS. In summary, the results suggest significant differences in the determinants of NWOM communication for respondents with and without prior experience transmitting NWOM communications on SNS. A post-hoc analysis by gender indicated no significant differences in the antecedents of NWOM communications on SNS. 


\section{Discussion}

In this study, we have attempted to examine the determinants of NWOM communications on SNS following a service failure in the online shopping context. The results of the empirical study indicated that contextual, individual, and social networking factors influence the customers' intentions to transmit NWOM communications on SNS. In particular, feeling of injustice, firm attribution, firm image, face concern, reappraisal emotion regulation, SNS use intensity, and tie strength were found to significantly impact the intentions to transmit NWOM communications on SNS.

\subsection{Theoretical implications}

This study contributes to the existing literature in several ways. First, sWOM has only recently received significant attention from managers and academicians. The emergence of social networking platforms has dramatically transformed the nature and content of customer conversations. These platforms allow customers to have direct, instantaneous, and expanded interaction with other networked customers. For example, the complaint posted by Mike Brown on his Facebook page sharing his awful experience with Wild Wings café went viral with 4,000 Facebook shares and 1000 comments prompting the service provider to issue an apology for the encounter (Ramsey, 2013). The persuasiveness and dynamic nature of SNS creates unique challenges for the service provider to interact, monitor, and communicate with the dissatisfied customers. Although social media has received considerable attention from researchers in recent years, there has been limited empirical work investigating WOM communication using SNS. For example, Clark (2013) noted that there is very little research regarding the role of social media platforms in complaints against service providers. In addressing this gap, the present study proposed and empirically examined an integrated model of determinants of NWOM communication using the emerging channel of SNS.

Prior research studies have mostly focused on understanding the process and outcomes of WOM communication. For example, De Bruyn and Lilien (2008) presented a hierarchical multistage model of the influence of WOM on the consumer decision-making process. Similarly, Chan and Ngai (2012) conceptualized WOM from an input-process-output (IPO) perspective. While these studies enhance our 
understanding of WOM communication, they did not address the reasons why customers transmit WOM communications using SNS. Jahn and Kunz (2012) noted that further research is needed to understand NWOM communication on social media platforms. Similarly, Jin, Liu and Austin (2014) suggested that additional research is needed to have a thorough and comprehensive understanding of product or service crises on social media platforms. Thus, the present study extends our current understanding by investigating the role of contextual, individual, and social networking factors influencing NWOM communications using SNS.

Second, few studies that exist on NWOM have majorly focused on contextual or situational factors. For instance, research works by Richins (1983), Kim et al. (2003) and Sengupta, Balaji, \& Krishnan (2015) have illustrated that service failure magnitude, failure attribution, and firm image may affect NWOM communication. However, there have been recent calls for research into understanding the role of the individual and online social networking factors in WOM communication. Specifically, Cheema and Kaikati (2010) and Cheung and Lee (2012) proposed that individual differences may exist in the customers' willingness to engage in WOM communication. Furthermore, Son et al. (2012) called for research into the effect of social networking features on consumer acceptance of the technology. In response to these calls, the present study considered contextual factors such as feeling of injustice, firm attribution, and firm image; and individual factors such as face concern and emotion regulation; and social networking factors such as SNS use intensity and tie strength in understanding NWOM communication using SNS following a service failure. This expands our understanding of the role of various factors influencing NWOM communication on SNS.

Third, online shopping is considered as an information-intensive industry (Kiang et al., 2011). An understanding of how technology impacts the accessibility of product and service information is crucial for service managers to understand how it may affect the purchase behaviour of other network members. Thus, an investigation of NWOM communication on SNS would provide insights into the evaluation process and decision-making of customers. Fourth, the results revealed that various contextual, individual, and social networking factors determine the likelihood NWOM communications on SNS. These findings enable 
managers to develop successful service recovery and social media webcare interventions. Finally, research studies on NWOM communication are less common than positive WOM communication. As positive WOM is three times more likely to be given than NWOM, prior studies have largely focused on positive word-of-mouth (Lien and Cao, 2014; Ng, David \& Dagger, 2011). However, NWOM communication is considered very diagnostic and a few studies have reported that it has greater influence on the decision-making of customers than positive word-of-mouth communication. Consequently, this study expands our understanding of WOM behaviour by investigating the factors determining NWOM communications on SNS following a service failure.

\subsection{Managerial implications}

With the increasing popularity of social media platforms, customers can now more easily communicate their dissatisfaction to a wider audience. The public nature of social media platforms permits other customers to read about negative experiences and this affects their opinions toward the service provider. With the service provider's reputation and future business at risk, it is imperative for service managers to monitor and address NWOM communications on SNS. This study offers several practical implications for managing NWOM communication on SNS.

Many researchers and practitioners suggest that service providers may require a new skill set to effectively manage NWOM communication on SNS. As customers do not direct their complaints to the service provider, it is up to the service provider to use monitoring tools to track NWOM communication on SNS and initiate contact with dissatisfied customers. Thus, the service provider should devote significant human and financial resources to monitoring and tracking social media platforms for NWOM communications. They can invest in various monitoring tools, such as social mention, tweet reach, or Hootsuite to track NWOM communications on SNS. A good monitoring system can aid early detection and allow the service provider to quickly communicate its commitment and competency, thereby avoiding potential public embarrassment and other consequences of NWOM communication on SNS. Moreover, dedicated social media teams can be established to respond to NWOM communications and provide 
customer support via SNS. Effective monitoring enables service providers to respond to NWOM communications on SNS with appropriate interventions.

The study findings show that various contextual, individual, and social networking factors determine the likelihood of NWOM communication on SNS. In case of contextual determinants, we found that injustice perception, firm attribution, and firm image are key antecedents of NWOM communication on SNS. The study findings pertaining to perceptions of injustice indicate that customers may engage in NWOM communication on SNS to not only communicate their dissatisfaction to other network members, but also to for the service provider to respond to their negative experience. When responding to NWOM communications on SNS, the service provider can either engage in proactive or reactive webcare interventions to mitigate the adverse effects. Proactive webcare refers to service recovery strategies or interventions posted proactively on SNS in response to NWOM communications. Reactive webcare includes interventions posted following specific requests from customers in their NWOM communication. We contend that a timely response to NWOM communications, either proactively or reactively, will help to resolve issues. This is particularly important because other customers on social media are watching; hence, a quick and effective response is critical. In short, the service provider should focus on responsiveness and fixing the service problem effectively, because a lack or delay of action can adversely affect the image of the service provider and create a major public crisis (Richins, 1983). Moreover, both proactive and reactive webcare increase customer satisfaction, loyalty, positive eWOM, and customer retention (Van Noort and Willemsen, 2012).

In their response to the NWOM communication, the service provider should acknowledge the complaint and apologize in general on SNS. The service provider may communicate politely that it was not aware of the problem and recognize that a service failure has occurred. It is argued that acknowledging the service failure may generate more goodwill than refuting or denying responsibility of the failed encounter. Refuting or denying the service failure communicates distrust and lack of empathy on the part of the service provider and this may discourage other network members from using or recommending the service provider. In response to NWOM communications, the service provider can paraphrase the negative experience as this 
reflects that they have thoroughly reviewed the problem. For example, the service provider can respond to NWOM communication as follows: "We regret to hear that your online shopping experience was marred by the delayed delivery of your product." This prevents the network members from drawing their own, negative inferences from the service failure.

Along with acknowledging the service failure, the service provider can offer public compensation as this represents a guarantee and commitment that customers will be fairly treated in the future. This is important, as other network members on SNS may perceive NWOM communications as an indication of a high likelihood of future service failure. Thus, they require a promise from the service provider that the service failure has been successfully resolved, and assurance that they would be compensated should service failure reoccur. Moreover, offering a public apology and acknowledgement may be effective in restoring customer face (Wan, 2013). This aids the customer in reappraising the service failure positively, and possibly modifying their emotional response to the negative service encounter. The results indicate that service providers can use the profiles of respondents (i.e. SNS use intensity, number of friends, and number of posts) in segmenting SNS users into target groups for understanding their propensity to engage in NWOM communication. In summary, the service provider must have a strong system in place for effectively tracking and managing NWOM communications on SNS. Furthermore, webcare interventions should include an acknowledgement, apology, compensation, and a promise that any injustice will be redressed.

\subsection{Limitations and future research directions}

Although this study expands our knowledge on an important topic, limitations must be noted, and viable prospects for further research should be identified. First, while the various contextual, individual, and social networking factors considered in the present study explained a reasonable amount of variance in NWOM communication on SNS, future research could examine extended factors. These may include the technical features of social networking platforms, social identity, altruism, and affective commitment towards the service provider to account for the remaining unexplored variance in NWOM communication. Additionally, as customers can share their negative experiences with both in-group and out-group members on 
(Schellekens, Verlegh, and Smidts, 2010), future research could examine the differential effects of various factors influencing NWOM to in-group and out-group members. Second, while the present study considered the potential antecedents of NWOM communication, future research should examine the consequences of NWOM communication on SNS. Extant literature suggests that dissatisfaction with a service provider leads to customer animosity and exit, which in turn adversely affects firm performance (e.g. sales revenue). Thus, future studies could examine the outcomes of NWOM communication on firm performance.

Third, by only measuring NWOM, this study did not address the difference between positive and negative WOM communication on SNS. Alexandrov, Lilly, and Babakus (2013) demonstrated that the motives for positive and negative WOM communication varies, a fruitful extension of this study might examine the differential effect of factors that determine positive and negative WOM communication on SNS. In addition, this study addressed only online service failures, and as service failures can occur online and offline, future studies could test this study model in both environments. Finally, social media platforms differ in their architecture, culture and norms. Consequently, future research should examine the determinants of NWOM communication on diverse social media platforms.

Despite the limitations of the present study, the findings provide important contributions to the information systems literature. We extended the prior studies on eWOM by proposing and empirically examining an integrated model of NWOM communication on SNS. The results show that contextual, individual and social factors, such as feeling of injustice, firm attribution, perceived firm image, face-concern, emotion regulation, SNS use intensity, and tie strength have a significant influence on customer intentions to transmit NWOM communications on SNS. These findings have significant implications for academicians and practitioners in managing customer NWOM communications on SNS.

\section{References}

Ahmad, I. (2015). Fascinating \#SocialMedia Stats 2015: Facebook, Twitter, Pinterest, Google+. http://www.digitalinformationworld.com/2015/02/fascinating-social-networking-stats-2015.html Accessed 22 June 2015.

Alexandrov, A., Lilly, B., \& Babakus, E. (2013). The effects of social-and self-motives on the intentions to share positive and negative word of mouth. Journal of the Academy of Marketing Science, 41(5), 531546. 
Alhidari, A., Iyer, P., \& Paswan, A. (2015). Personal level antecedents of eWOM and purchase intention, on social networking sites. Journal of Customer Behaviour, 14(2), 107-125.

Anderson, J. C., \& Gerbing, D. W. (1988). Structural equation modeling in practice: A review and recommended two-step approach. Psychological bulletin, 103(3), 411-423.

Ba, S., \& Pavlou, P. A. (2002). Evidence of the effect of trust building technology in electronic markets: Price premiums and buyer behavior. MIS quarterly, 26(3), 243-268.

Bailey, A. A. (2004). Thiscompanysucks. com: the use of the Internet in negative consumer-to-consumer articulations. Journal of Marketing Communications, 10(3), 169-182.

Balaji, M. S., \& Sarkar, A. (2013). Does successful recovery mitigate failure severity? A study of the behavioral outcomes in Indian context. International Journal of Emerging Markets, 8(1), 65-81.

Baldacci, K. (2013). 5 Reasons why the social customer is today's undeniable authority. http://blogs.salesforce.com/company/2013/07/the-social-customer.html. Accessed 07 January 2015.

Baltar, F., \& Brunet, I. (2012). Social research 2.0: virtual snowball sampling method using Facebook. Internet Research, 22(1), 57-74.

Bambauer-Sachse, S., \& Mangold, S. (2011). Brand equity dilution through negative online word-ofmouth communication. Journal of Retailing and Consumer Services, 18(1), 38-45.

Bambauer-Sachse, S., \& Mangold, S. (2013). Do consumers still believe what is said in online product reviews? A persuasion knowledge approach. Journal of Retailing and Consumer Services, 20(4), 373-381.

Berry, R., Tanford, S., Montgomery, R., \& Green, A. (2014). How We Complain The Effect of Personality on Consumer Complaint Channels. Journal of Hospitality \& Tourism Research, Before print.

Brown, J., Broderick, A. J., \& Lee, N. (2007). Word of mouth communication within online communities: Conceptualizing the online social network. Journal of interactive marketing, 21(3), 2-20.

Brown, J. J., \& Reingen, P. H. (1987). Social ties and word-of-mouth referral behavior. Journal of Consumer research, 14(3), 350-362.

Cha, J. (2009). Shopping on social networking Web sites: Attitudes toward real versus virtual items. Journal of Interactive Advertising, 10(1), 77-93.

Chan, Y. Y., \& Ngai, E. W. T. (2011). Conceptualising electronic word of mouth activity: An inputprocess-output perspective. Marketing Intelligence \& Planning, 29(5), 488-516.

Chang, H. H., \& Wu, L. H. (2014). An examination of negative e-WOM adoption: Brand commitment as a moderator. Decision Support Systems, 59, 206-218.

Chang, H. H., Tsai, Y. C., Wong, K. H., Wang, J. W., \& Cho, F. J. (2015). The effects of response strategies and severity of failure on consumer attribution with regard to negative word-of-mouth. Decision Support Systems, 71, 48-61.

Cheema, A., \& Kaikati, A. M. (2010).The effect of need for uniqueness on word of mouth. Journal of Marketing Research, 47(3), 553-563.

Cheung, C. M., \& Lee, M. K. (2012). What drives consumers to spread electronic word of mouth in online consumer-opinion platforms? Decision Support Systems, 53(1), 218-225.

Cheung, C. M., \& Thadani, D. R. (2012). The impact of electronic word-of-mouth communication: A literature analysis and integrative model. Decision Support Systems, 54(1), 461-470.

Cohen, S., \& Wills, T. A. (1985). Stress, social support, and the buffering hypothesis. Psychological bulletin, 98(2), 310-357. 
Chu, S. C., \& Kim, Y. (2011). Determinants of consumer engagement in electronic word-of-mouth (eWOM) in social networking sites. International journal of Advertising, 30(1), 47-75.

Chung, J. Y., \& Buhalis, D. (2008). Information needs in online social networks. Information Technology \& Tourism, 10(4), 267-281.

Clark, J. (2013). Conceptualising Social Media as Complaint Channel. Promotional Communications, 1(1), 105-124.

Cutrona, C. E., \& Russell, D. W. (1987). The provisions of social relationships and adaptation to stress. Advances in personal relationships, 1(1), 37-67.

Daugherty, T., \& Hoffman, E. (2014). eWOM and the importance of capturing consumer attention within social media. Journal of Marketing Communications, 20(1-2), 82-102.

Day, R. L. (1977). Extending the concept of consumer satisfaction. Advances in consumer research, 4(1), $149-154$.

De Bruyn, A., \& Lilien, G. L. (2008). A multi-stage model of word-of-mouth influence through viral marketing. International Journal of Research in Marketing, 25(3), 151-163.

Ehring, T., Tuschen-Caffier, B., Schnülle, J., Fischer, S., \& Gross, J. J. (2010). Emotion regulation and vulnerability to depression: spontaneous versus instructed use of emotion suppression and reappraisal. Emotion, 10(4), 563-572.

Eisingerich, A. B., Chun, H. H., Liu, Y., Jia, H. M., \& Bell, S. J. (2015). Why recommend a brand faceto-face but not on Facebook? How word-of-mouth on online social sites differs from traditional word-ofmouth. Journal of Consumer Psychology, 25, 120-128.

Faul, F., Erdfelder, E., Lang, A. G., \& Buchner, A. (2007). G* Power 3: A flexible statistical power analysis program for the social, behavioral, and biomedical sciences. Behavior research methods, 39(2), $175-191$.

Fornell, C., \& Larcker, D. F. (1981). Evaluating structural equation models with unobservable variables and measurement error. Journal of Marketing Research, 18(1), 375-381.

Festinger, L.A. (1957). A theory of cognitive dissonance. Stanford: Stanford University Press.

Granovetter, M. S. (1973). The strength of weak ties. American journal of sociology, 78(6), 1360-1380.

Grégoire, Y., Salle, A., \& Tripp, T. M. (2014). Managing social media crises with your customers: The good, the bad, and the ugly. Business Horizons, 58(2), 173-182.

Gross, J. J. (2002). Emotion regulation: Affective, cognitive, and social consequences. Psychophysiology, 39(3), 281-291.

Gross, J. J., \& John, O. P. (2003). Individual differences in two emotion regulation processes: implications for affect, relationships, and well-being. Journal of personality and social psychology, 85(2), 348-362.

Hair, J. F., Black, W.C., Babin, B. J., \& Anderson, R. E. (2009). Multivariate Data Analysis, 7th Edition, Prentice Hall.

Henderson, G. R., Guzmán, F., Huff, L., \& Motley, C. M. (2013). The Ian's pizza tribe: Reconceptualizing cross-cultural research in the digital age. Journal of Business Research, 66(3), 283-287.

Hennig-Thurau, T., Gwinner, K. P., Walsh, G., \& Gremler, D. D. (2004). Electronic word-of-mouth via consumer-opinion platforms: what motivates consumers to articulate themselves on the internet? Journal of interactive marketing, 18(1), 38-52. 
Hess, R. L. (2008).The impact of firm reputation and failure severity on customers' responses to service failures. Journal of Services Marketing, 22(5), 385-398.

Hoelter, J. W. (1983). The analysis of covariance structures goodness-of-fit indices. Sociological Methods \& Research, 11(3), 325-344.

Jahn, B., \& Kunz, W. (2012). How to transform consumers into fans of your brand. Journal of Service Management, 23(3), 344-361.

Jeong, E., \& Jang, S. S. (2011). Restaurant experiences triggering positive electronic word-of-mouth (eWOM) motivations. International Journal of Hospitality Management, 30(2), 356-366.

Jin, Y., Liu, B. F., \& Austin, L. L. (2011). Examining the role of social media in effective crisis management: The effects of crisis origin, information form, and source on publics' crisis responses. Communication Research, 41(1), 74-94.

Kemp, S. (2015). Digital, Social \& Mobile Worldwide in 2015. http://wearesocial.net/blog/2015/01/digital-social-mobile-worldwide-2015/ Accessed 22 June 2015.

Kiang, M. Y., Ye, Q., Hao, Y., Chen, M., \& Li, Y. (2011). A service-oriented analysis of online product classification methods. Decision Support Systems, 52(1), 28-39.

Kim, C., Kim, S., Im, S., \& Shin, C. (2003).The effect of attitude and perception on consumer complaint intentions. Journal of consumer marketing, 20(4), 352-371.

Kuo, Y. F., Yen, S. T., \& Chen, L. H. (2011). Online auction service failures in Taiwan: Typologies and recovery strategies. Electronic Commerce Research and Applications, 10(2), 183-193.

Lee, J., Park, D. H., \& Han, I. (2008). The effect of negative online consumer reviews on product attitude: An information processing view. Electronic Commerce Research and Applications, 7(3), 341-352.

Lee, Y. L., Sparks, B., \& Butcher, K. (2013). Service encounters and face loss: Issues of failures, fairness, and context. International Journal of Hospitality Management, 34, 384-393.

Liang, T. P., Ho, Y. T., Li, Y. W., \& Turban, E. (2011). What drives social commerce: The role of social support and relationship quality? International Journal of Electronic Commerce, 16(2), 69-90.

Lien, C. H., \& Cao, Y. (2014). Examining WeChat users' motivations, trust, attitudes, and positive wordof-mouth: Evidence from China. Computers in Human Behavior, 41, 104-111.

Li, F., \& Du, T. C. (2011). Who is talking? An ontology-based opinion leader identification framework for word-of-mouth marketing in online social blogs. Decision Support Systems, 51(1), 190-197.

Liao, S., \& Cheng, C. C. (2013). Consumer evaluation of self-service innovation failure: the effect of brand equity and attribution. The Service Industries Journal, 33(5), 467-485.

Lin, H., Fan, W., \& Chau, P. Y. (2014). Determinants of users' continuance of SNS: A self-regulation perspective. Information \& Management, 51(5), 595-603.

Lindell, M. K., \& Whitney, D. J. (2001). Accounting for common method variance in cross-sectional research designs. Journal of applied psychology, 86(1), 114-121.

Luo, C., Luo, X. R., Schatzberg, L., \& Sia, C. L. (2013). Impact of informational factors on online recommendation credibility: The moderating role of source credibility. Decision Support Systems, 56, 92102.

Mattila, A. S., \& Cho, W. (2011). The role of self-service technologies in restoring justice. Journal of Business Research, 64(4), 348-355.

Moore, S. A., Zoellner, L. A., \& Mollenholt, N. (2008). Are expressive suppression and cognitive reappraisal associated with stress-related symptoms? Behaviour research and therapy, 46(9), 993-1000. 
Moorman, C., Deshpande, R., \& Zaltman, G. (1993). Factors affecting trust in market research relationships. The Journal of Marketing, 57(1), 81-101.

Ng, S., David, M. E., \& Dagger, T. S. (2011). Generating positive word-of-mouth in the service experience. Managing Service Quality: An International Journal, 21(2), 133-151.

Pan, L. Y., \& Chiou, J. S. (2011). How much can you trust online information? Cues for perceived trustworthiness of consumer-generated online information. Journal of Interactive Marketing, 25(2), 67-74.

Petersen, R. (2013). 38 surprising facts about trust in social media. http://barnraisersllc.com/2013/09/surprising-facts-trust-social-media/ Accessed 26 June 2015.

Pfeffer, J., Zorbach, T., \& Carley, K. M. (2014). Understanding online firestorms: Negative word-ofmouth dynamics in social media networks. Journal of Marketing Communications, 20(1-2), 117-128.

Podsakoff, P. M., MacKenzie, S. B., Lee, J. Y., \& Podsakoff, N. P. (2003). Common method biases in behavioral research: a critical review of the literature and recommended remedies. Journal of applied psychology, 88(5), 879 .

Ramsey, D.X. (2013). Wild Wings Café apologizes after patron posts discrimination complaint to Facebook. $\quad$ http://thegrio.com/2013/09/03/wild-wings-cafe-apologizes-after-patron-postsdiscrimination-complaint-to-facebook/. Accessed 08 January 2015.

Richins, M. L. (1983). Negative word-of-mouth by dissatisfied consumers: A pilot study. The journal of marketing, 47(1), 68-78.

Roggio, A., (2011). 3 ways social media affects brands. http://www.practicalecommerce.com/articles/3202-3-Ways-Social-Media-Affects-Brands. Accessed 25 June 2015.

Schellekens, G. A., Verlegh, P. W., \& Smidts, A. (2010). Language abstraction in word of mouth. Journal of Consumer Research, 37(2), 207-223.

Sen, S., \& Lerman, D. (2007). Why are you telling me this? An examination into negative consumer reviews on the web. Journal of interactive marketing, 21(4), 76-94.

Sengupta, A. S., Balaji, M. S., \& Krishnan, B. C. (2015). How customers cope with service failure? A study of brand reputation and customer satisfaction. Journal of Business Research, 68(3), 665-674.

Smyth, S. (2015). How online shopping has turned us into a nation of moaners: Number of complaints about internet purchases doubles to more than 66 million in a year. http://www.dailymail.co.uk/news/article2945399/How-online-shopping-turned-nation-moaners-Number-complaints-internet-purchases-doubled66million-2014.html. Accessed 27 June 2015.

Son, J., Sadachar, A., Manchiraju, S., Fiore, A. M., \& Niehm, L. S. (2012).Consumer adoption of online collaborative customer co-design. Journal of Research in Interactive Marketing, 6(3), 180-197.

Sun, J. (2014). How risky are services? An empirical investigation on the antecedents and consequences of perceived risk for hotel service. International Journal of Hospitality Management, 37, 171-179.

Sun, H., \& Zhang, P. (2006). The role of moderating factors in user technology acceptance. International Journal of Human-Computer Studies, 64(2), 53-78.

Tufekci, Z., \& Wilson, C. (2012). Social media and the decision to participate in political protest: Observations from Tahrir Square. Journal of Communication,62(2), 363-379.

Valenzuela, S., Park, N., \& Kee, K. F. (2009). Is There Social Capital in a Social Network Site? Facebook Use and College Students' Life Satisfaction, Trust, and Participation1. Journal of Computer-Mediated Communication, 14(4), 875-901. 
Van Noort, G., \& Willemsen, L. M. (2012). Online damage control: The effects of proactive versus reactive webcare interventions in consumer-generated and brand-generated platforms. Journal of Interactive Marketing, 26(3), 131-140.

Veloutsou, C., \& Moutinho, L. (2009). Brand relationships through brand reputation and brand tribalism. Journal of Business Research, 62(3), 314-322.

Verhagen, T., Nauta, A., \& Feldberg, F. (2013). Negative online word-of-mouth: Behavioral indicator or emotional release? Computers in Human Behavior, 29(4), 1430-1440.

Vermeulen, I. E., \& Seegers, D. (2009). Tried and tested: The impact of online hotel reviews on consumer consideration. Tourism Management, 30(1), 123-127.

Ward, J. C., \& Ostrom, A. L. (2006). Complaining to the masses: The role of protest framing in customercreated complaint web sites. Journal of Consumer Research, 33(2), 220-230.

Wan, L. C. (2013). Culture's impact on consumer complaining responses to embarrassing service failure. Journal of Business Research, 66(3), 298-305.

Wang, X., Yu, C., \& Wei, Y. (2012). Social media peer communication and impacts on purchase intentions: A consumer socialization framework. Journal of Interactive Marketing, 26(4), 198-208.

Weiner, B. (1985). An attributional theory of achievement motivation and motion. Psychological review, 92(4), 548-573.

Weun, S., Beatty, S. E., \& Jones, M. A. (2004). The impact of service failure severity on service recovery evaluations and post-recovery relationships. Journal of Services Marketing, 18(2), 133-146.

Wolny, J., \& Mueller, C. (2013). Analysis of fashion consumers' motives to engage in electronic wordof-mouth communication through social media platforms. Journal of Marketing Management, 29(5-6), $562-583$.

Xu, C., Ryan, S., Prybutok, V., \& Wen, C. (2012). It is not for fun: An examination of social network site usage. Information \& Management, 49(5), 210-217.

Yen, H. R., Gwinner, K. P., \& Su, W. (2004). The impact of customer participation and service expectation on locus attributions following service failure. International Journal of Service Industry Management, 15(1), 7-26.

Yoo, C. W., Kim, Y. J., \& Sanders, G. L. (2015). The impact of interactivity of electronic word of mouth systems and E-Quality on decision support in the context of the e-marketplace. Information \& Management, 52(4), 496-505.

Zajonc, R. B. (1980). Feeling and thinking: Preferences need no inferences. American psychologist, 35(2), 151.

Zhang, J. Q., Craciun, G., \& Shin, D. (2010). When does electronic word-of-mouth matter? A study of consumer product reviews. Journal of Business Research, 63(12), 1336-1341.

Zhang, Y., Feick, L., \& Mittal, V. (2014). How males and females differ in their likelihood of transmitting negative word of mouth. Journal of Consumer Research, 40(6), 1097-1108.

Zhao, J., Wu, J., Feng, X., Xiong, H., \& Xu, K. (2012). Information propagation in online social networks: a tie-strength perspective. Knowledge and Information Systems, 32(3), 589-608.

Zhu, Z., Nakata, C., Sivakumar, K., \& Grewal, D. (2013). Fix It or Leave It? Customer Recovery from Self-service Technology Failures. Journal of Retailing, 89(1), 15-29. 


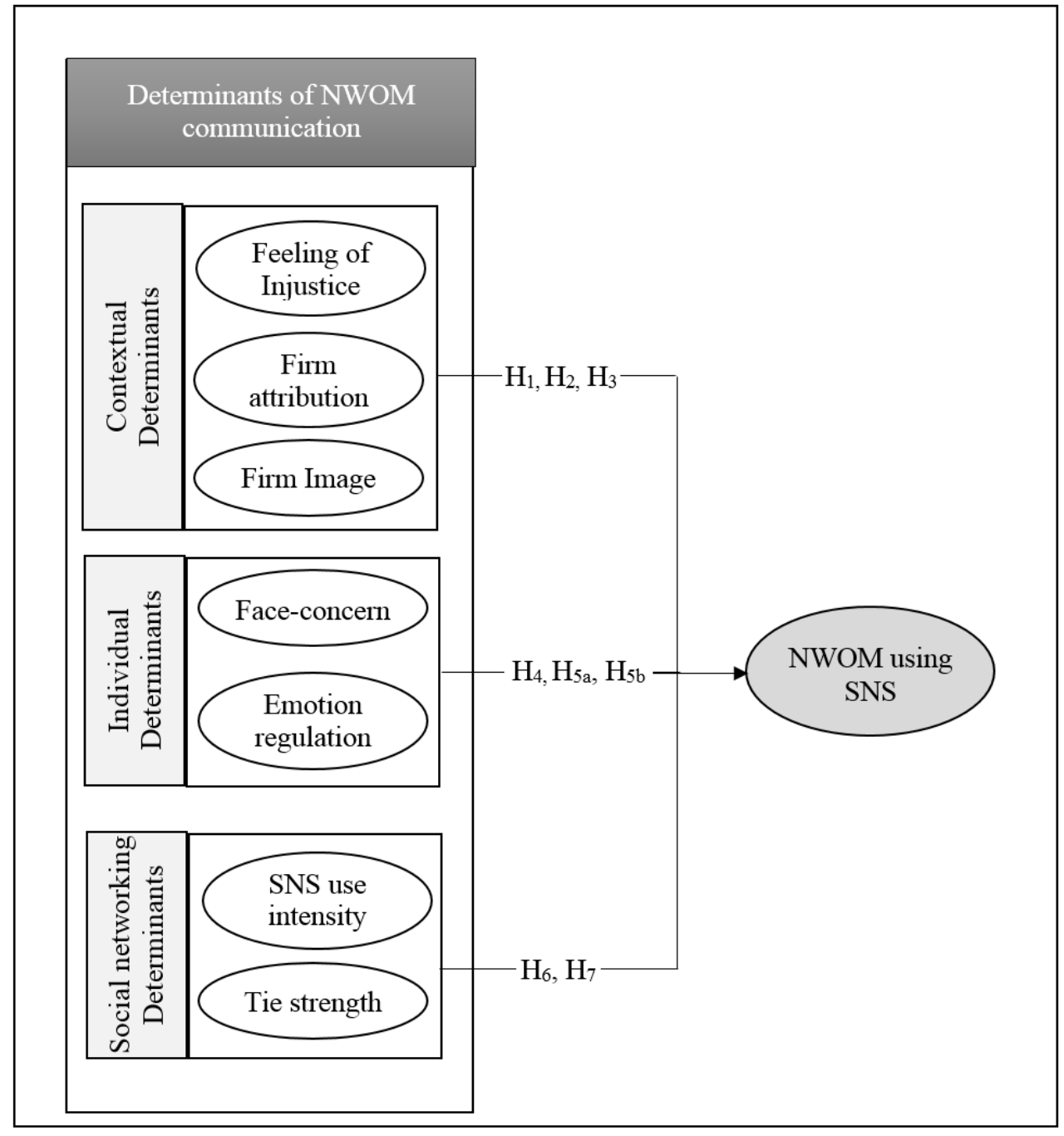

Figure 1. Conceptual framework of the study 


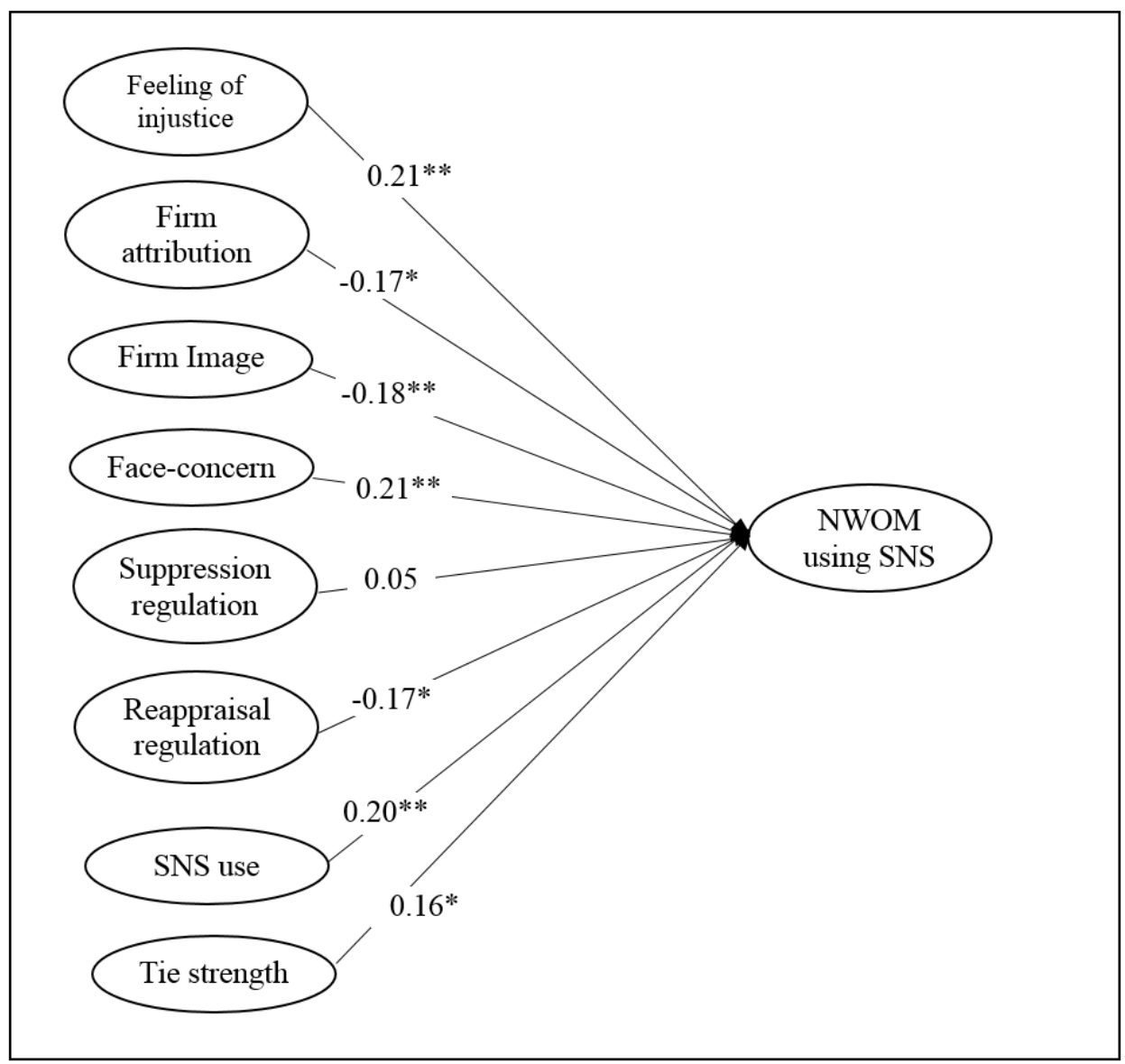

Figure 2. Structural equation modelling results ${ }^{*} \mathrm{p}<0.05, * * \mathrm{p}<0.01$ 
Tables

Table 1. Comparison between WOM, eWOM, and sWOM

\begin{tabular}{|c|c|c|c|}
\hline & WOM & eWOM & sWOM \\
\hline Mode & $\begin{array}{l}\text { Usually oral or verbal } \\
\text { One-to-one } \\
\text { communication } \\
\text { Simultaneous } \\
\text { communication }\end{array}$ & $\begin{array}{l}\text { Various online forms } \\
\text { One-to-one and one-to- } \\
\text { many communication } \\
\text { Simultaneous and non- } \\
\text { simultaneous } \\
\text { communication }\end{array}$ & $\begin{array}{l}\text { Social media platforms } \\
\text { One-to-one and one-to- } \\
\text { many communication } \\
\text { Mostly non- } \\
\text { simultaneous } \\
\text { communication }\end{array}$ \\
\hline Receivers & Individuals & $\begin{array}{l}\text { Individuals, small groups } \\
\text { and public }\end{array}$ & $\begin{array}{c}\text { Individuals, social } \\
\text { networks and public }\end{array}$ \\
\hline Senders & $\begin{array}{l}\text { Identifiable and } \\
\text { accountable }\end{array}$ & $\begin{array}{l}\text { Identifiable or } \\
\text { unidentifiable }\end{array}$ & $\begin{array}{l}\text { Identifiable and } \\
\text { accountable }\end{array}$ \\
\hline Scope & $\begin{array}{l}\text { Geographical and } \\
\text { temporal constraints }\end{array}$ & $\begin{array}{l}\text { Limited geographical and } \\
\text { temporal constraints }\end{array}$ & $\begin{array}{l}\text { Limited geographical } \\
\text { and temporal constraints }\end{array}$ \\
\hline $\begin{array}{l}\text { Connection } \\
\text { between the } \\
\text { receivers and } \\
\text { senders }\end{array}$ & Strong ties & Strong or weak ties & $\begin{array}{l}\text { Combination of strong } \\
\text { and weak ties }\end{array}$ \\
\hline $\begin{array}{l}\text { Risk associated } \\
\text { with WOM }\end{array}$ & Low social risk & Low social risk & Greater social risk \\
\hline Speed of diffusion & Slow & Fast & Fast \\
\hline
\end{tabular}


Table 2. Summary of the select studies on word-of-mouth communication

\begin{tabular}{|c|c|c|c|}
\hline Author(s) & Context & Method & Key Findings \\
\hline $\begin{array}{l}\text { Ba and Pavlou } \\
\text { (2002) }\end{array}$ & Online auction & $\begin{array}{l}393 \text { participants } \\
\text { Regression } \\
\text { analysis }\end{array}$ & $\begin{array}{c}\text { Negative ratings were found to have a } \\
\text { stronger negative effect on trust in seller than } \\
\text { positive ratings. }\end{array}$ \\
\hline Bailey (2004) & $\begin{array}{l}\text { Corporate } \\
\text { complaint } \\
\text { websites }\end{array}$ & $\begin{array}{l}158 \text { participants } \\
\text { Mann-Whitney } \\
\text { U tests }\end{array}$ & $\begin{array}{c}\text { Attitude towards complaining was found to } \\
\text { have a significant effect on decision to not } \\
\text { shop with the company that was the target of } \\
\text { negative reviews }\end{array}$ \\
\hline $\begin{array}{l}\text { Ward and Ostrom } \\
\text { (2006) }\end{array}$ & $\begin{array}{l}\text { Consumer } \\
\text { constructed } \\
\text { complaint web } \\
\text { sites }\end{array}$ & $\begin{array}{l}40 \text { protest sites } \\
\text { Content analysis }\end{array}$ & $\begin{array}{l}\text { Protest sites were created to spread the } \\
\text { NWOM against a firm that has wronged } \\
\text { them. Further, they constructed their NWOM } \\
\text { using recurrent, specific and rhetorical tactics } \\
\text { such as injustice, identity framing and agency } \\
\text { framing }\end{array}$ \\
\hline $\begin{array}{l}\text { Sen and Lerman } \\
\text { (2007) }\end{array}$ & $\begin{array}{l}\text { Book and } \\
\text { presentation } \\
\text { program - } \\
\text { Review sites }\end{array}$ & $\begin{array}{c}132 \text { participants } \\
\text { Analysis of } \\
\text { variance }\end{array}$ & $\begin{array}{l}\text { Consumers attribute the negative reviews } \\
\text { about utilitarian product to external } \\
\text { motivations and find them more useful than } \\
\text { those for hedonic products. }\end{array}$ \\
\hline $\begin{array}{l}\text { Lee, Park and Han } \\
\text { (2008) }\end{array}$ & $\begin{array}{l}\text { Online } \\
\text { consumer } \\
\text { reviews }\end{array}$ & $\begin{array}{c}248 \text { participants } \\
\text { Analysis of } \\
\text { variance }\end{array}$ & $\begin{array}{l}\text { The proportion and quality of negative online } \\
\text { consumer reviews affect product attitude. }\end{array}$ \\
\hline $\begin{array}{l}\text { Vermeulen and } \\
\text { Seegers (2009) }\end{array}$ & $\begin{array}{l}\text { Travel - } \\
\text { Website } \\
\text { review }\end{array}$ & $\begin{array}{l}168 \text { participants } \\
\text { Repeated } \\
\text { measures } \\
\text { ANOVA }\end{array}$ & $\begin{array}{c}\text { Negative reviews were found to yield } \\
\text { negative attitude change for lesser known } \\
\text { hotel. However, no relationship was observed } \\
\text { between negative reviews and hotel } \\
\text { consideration. }\end{array}$ \\
\hline $\begin{array}{l}\text { Zhang, Craciun } \\
\text { and Shin (2010) }\end{array}$ & $\begin{array}{l}\text { Software } \\
\text { programs - } \\
\text { Amazon.com }\end{array}$ & $\begin{array}{l}27,985 \text { product } \\
\text { reviews } \\
\text { Binary logit } \\
\text { model }\end{array}$ & $\begin{array}{l}\text { Negative online reviews were perceived as } \\
\text { more persuasive than positive reviews for } \\
\text { products associated with prevention } \\
\text { consumption goals. }\end{array}$ \\
\hline $\begin{array}{l}\text { Bambauer-Sachse } \\
\text { and Mangold } \\
\text { (2011) }\end{array}$ & $\begin{array}{l}\text { Computer } \\
\text { notebook and } \\
\text { digital camera } \\
\text {-Opinion } \\
\text { platforms }\end{array}$ & $\begin{array}{l}216 \text { participants } \\
\text { Analysis of } \\
\text { variance }\end{array}$ & $\begin{array}{l}\text { Negative online reviews have detrimental } \\
\text { effect on consumer-based brand equity } \\
\text { leading to significant brand dilution. This } \\
\text { effect was observed independent of prior } \\
\text { product knowledge and person-specific } \\
\text { variables. }\end{array}$ \\
\hline $\begin{array}{l}\text { Pan and Chiou } \\
\text { (2011) }\end{array}$ & $\begin{array}{l}\text { Discussion } \\
\text { board }\end{array}$ & $\begin{array}{l}284 \text { participants } \\
\text { Structural } \\
\text { equation } \\
\text { modeling }\end{array}$ & $\begin{array}{l}\text { For credence products online NWOM posted } \\
\text { by people with strong ties are considered as } \\
\text { more trustworthy. On the contrary, for } \\
\text { experience products either online positive or } \\
\text { negative WOM posted by someone with } \\
\text { close relationship is considered as } \\
\text { trustworthy. }\end{array}$ \\
\hline
\end{tabular}




\begin{tabular}{|c|c|c|c|}
\hline $\begin{array}{l}\text { Cheung and } \\
\text { Thadani (2012) }\end{array}$ & $\begin{array}{l}\text { Online } \\
\text { consumer } \\
\text { reviews }\end{array}$ & $\begin{array}{l}\text { Conceptual } \\
\text { paper }\end{array}$ & $\begin{array}{l}\text { A systematic review of electronic WOM was } \\
\text { carried out to identify key factors that impact } \\
\text { the influence of electronic negative and } \\
\text { positive WOM in consumer behavior. }\end{array}$ \\
\hline $\begin{array}{c}\text { Van Noort \& } \\
\text { Willemsen (2012) }\end{array}$ & $\mathrm{B} \log \mathrm{s}$ & $\begin{array}{l}163 \text { participants } \\
\text { Analysis of } \\
\text { variance }\end{array}$ & $\begin{array}{l}\text { The results show that customers evaluated a } \\
\text { brand more favorably when the firm responds } \\
\text { reactively and proactively to online NWOM } \\
\text { than when they do not. }\end{array}$ \\
\hline $\begin{array}{l}\text { Bambauer-Sachse } \\
\text { and Mangold } \\
\text { (2013) }\end{array}$ & $\begin{array}{l}\text { Online } \\
\text { product } \\
\text { reviews }\end{array}$ & $\begin{array}{l}1280 \\
\text { participants } \\
\text { Regression } \\
\text { analysis }\end{array}$ & $\begin{array}{c}\text { The effect of negative product reviews on } \\
\text { product evaluation was weaker when } \\
\text { consumers had knowledge that reviews can } \\
\text { be manipulated and when provided less } \\
\text { credible source. }\end{array}$ \\
\hline $\begin{array}{l}\text { Verhagen, Nauta } \\
\text { and Feldberg } \\
\text { (2013) }\end{array}$ & $\begin{array}{l}\text { Telecom } \\
\text { providers } \\
\text { Consumer } \\
\text { discussion } \\
\text { forums }\end{array}$ & $\begin{array}{l}95 \text { participants } \\
\text { Structural } \\
\text { equation } \\
\text { modeling }\end{array}$ & $\begin{array}{c}\text { Results showed that positive and negative } \\
\text { affect together explained about } 47 \% \text { of the } \\
\text { variance in negative online word-of-mouth. } \\
\text { Further, the effect of NWOM on switching } \\
\text { and repatronage was moderated by } \\
\text { consumer's desire to help other community } \\
\text { members. }\end{array}$ \\
\hline $\begin{array}{l}\text { Chang and Wu } \\
\text { (2014) }\end{array}$ & $\begin{array}{l}\text { Coffee store } \\
\text { Blog web site }\end{array}$ & $\begin{array}{l}504 \text { participants } \\
\text { Analysis of } \\
\text { variance }\end{array}$ & $\begin{array}{l}\text { Perceived information credibility positively } \\
\text { impacts the adoption of negative online } \\
\text { word-of-mouth. }\end{array}$ \\
\hline $\begin{array}{l}\text { Chang et al. } \\
\text { (2015) }\end{array}$ & $\begin{array}{l}\text { Online } \\
\text { shopping }\end{array}$ & $\begin{array}{l}282 \text { participants } \\
\text { Analysis of } \\
\text { variance and } \\
\text { Structural } \\
\text { equation } \\
\text { modeling }\end{array}$ & $\begin{array}{l}\text { Accommodation and defensive response } \\
\text { strategies and failure severity affect customer } \\
\text { attribution, and this has a negative impact on } \\
\text { firm reputation and positive effect on } \\
\text { negative word-of-mouth. }\end{array}$ \\
\hline $\begin{array}{c}\text { Yoo, Kim and } \\
\text { Sanders (2015) }\end{array}$ & $\begin{array}{l}\text { Online } \\
\text { Shopping }\end{array}$ & $\begin{array}{l}313 \text { participants } \\
\text { Partial least } \\
\text { squares method }\end{array}$ & $\begin{array}{l}\text { Interactivity of electronic WOM system } \\
\text { determined by reciprocity, responsiveness, } \\
\text { nonverbal information, speed of response } \\
\text { influences the decision support satisfaction } \\
\text { and loyalty towards the website. }\end{array}$ \\
\hline
\end{tabular}




\section{Table 3. Measurement models reliability and validity results}

\section{Constructs and Indicators \\ $\lambda$}

$\alpha$

Feeling of Injustice (FI)

I consider the service failure encounter with the online shopping to be severe

0.89

The service failure encounter with the online shopping made me feel very angry

$\begin{array}{llll}0.87 & 0.89 & 0.90 & 0.75\end{array}$

The service failure encounter with the online shopping was

unpleasant to me

\section{Firm Attribution (FA)}

The online retailer is responsible for the failed service encounter

The service failure was due to the online retailer/or its employees

\section{Perceived Firm Image (FI)}

The online shopping retailer is reputable

0.83

The online shopping retailer is trustworthy

The online shopping retailer makes honest claims

$$
\text { Face-concern (FC) }
$$

I care about praises and criticisms from others.

0.68

0.81

$0.70 \quad 0.72 \quad 0.55$

0.80

0.93

$\begin{array}{lll}0.90 & 0.90 & 0.75\end{array}$

0.86

I care about others' attitudes toward me.

0.76

0.77

I hate being taken lightly.

0.85

I will be very angry if others are impolite to me.

0.86

$0.93 \quad 0.94 \quad 0.71$

I will be very happy if I am treated with respect.

0.92

I will be very upset if I am criticized in public. $\quad 0.89$

Suppression Emotion Regulation (SER)

I control my emotions by not expressing them.

When I am feeling negative emotions, I make sure not to express them.

0.85

0.75

$\begin{array}{lll}0.76 & 0.78 \quad 0.64\end{array}$

\section{Reappraisal Emotion Regulation (RER)}

I control my emotions by changing the way I think about the situation I'm in.

When I want to feel less negative emotion, I change the way I'm thinking about the situation.

0.88

0.75

$0.77 \quad 0.79$

0.56

When I'm faced with a stressful situation, I make myself think about it in a way that helps me stay calm.

0.58

\section{SNS Use Intensity ( $S U)$}

[SNS] is part of my everyday activity

0.78

I am proud to tell others I am on [SNS]

0.81

[SNS] has become part of my daily routine

0.78

$0.85 \quad 0.86 \quad 0.56$

I feel out of touch when I haven't logged onto [SNS] for a day

0.74

I feel I am part of the [SNS] community

0.61

Tie Strength (TS)

I share personal confidences with my friends in SNS

0.75

I spend some free time socializing with my friends in SNS?

0.86

I would perform a large favour for my friends in SNS?

0.85

$\begin{array}{lll}0.89 & 0.90 & 0.68\end{array}$

My friends in SNS will perform a large favour for me?

0.83 


\section{Negative Word-of-Mouth (NWOM)}

You will tell about the negative service encounter with the online retailer using SNS platform

Very unlikely/Very likely

0.93

Inclined not to/Inclined to

$\begin{array}{lll}0.89 & 0.93 & 0.93\end{array}$

0.83

Definitely will not/Definitely will

0.91

Measurement model fit statistics: $\chi^{2}=458.20, \mathrm{df}=393, \chi^{2} / \mathrm{df}=1.166, \mathrm{CFI}=0.983, \mathrm{IFI}=0.983, \mathrm{TLI}=$ 0.979, RMSEA $=0.028$.

Note: $\lambda$ - Standardized factor loadings, $\alpha$-Cronbach's alpha, $\rho$-Composite reliability, AVE - Average variance extracted.

\begin{tabular}{lccccccccc}
\hline \multicolumn{8}{c}{ Table 4. Correlations and discriminant validity of the constructs } \\
\hline \multicolumn{1}{c}{ FI } & FA & FI & FC & SER & RER & SU & TS & NWOM \\
\hline FI & 0.87 & & & & & & & & \\
FA & $-0.14^{*}$ & 0.74 & & & & & & & \\
FI & 0.07 & -0.10 & 0.87 & & & & & & \\
FC & -0.06 & $0.15^{*}$ & -0.04 & 0.84 & & & & & \\
SER & $0.16^{*}$ & -0.13 & $0.17^{*}$ & -0.08 & 0.79 & & & & \\
RER & -0.02 & $-0.18^{*}$ & 0.02 & -0.03 & $0.28^{* *}$ & 0.75 & & & \\
SU & 0.10 & 0.04 & -0.09 & 0.04 & -0.03 & 0.03 & 0.75 & & \\
TS & $0.23^{* *}$ & -0.06 & $-0.20^{* *}$ & -0.02 & -0.07 & -0.06 & $0.36^{* *}$ & 0.83 & \\
NWOM & $0.28^{* *}$ & $-0.15^{*}$ & $-0.16^{*}$ & $-0.23^{* *}$ & 0.02 & 0.09 & $0.26^{* *}$ & $0.30^{* *}$ & 0.91 \\
& & & & & & & & & \\
Mean & 4.71 & 3.92 & 4.96 & 3.84 & 4.83 & 4.12 & 4.00 & 3.92 & 4.16 \\
SD & 1.53 & 1.28 & 1.50 & 1.26 & 1.27 & 1.46 & 0.90 & 1.32 & 1.71 \\
\hline
\end{tabular}

Note: Diagonal values represent square-root of average variance extracted scores of constructs. $* p<0.05, * * p<0.01$.

Table 5. Post-hoc comparison

\begin{tabular}{ccccccc}
\hline Structural paths & \multicolumn{2}{c}{ No prior } & \multicolumn{2}{c}{$\begin{array}{c}\text { Prior } \\
\text { experience }\end{array}$} & $\begin{array}{c}\text { T-tests across } \\
\text { groups }\end{array}$ & p value \\
& $\beta$ & SE & $\beta$ & SE & & \\
FI $\rightarrow$ NWOM & $0.36^{*}$ & 0.17 & $0.17^{* *}$ & 0.10 & 1.01 & 0.31 \\
FA $\rightarrow$ NWOM & $-0.33^{*}$ & 0.15 & -0.11 & 0.14 & 1.07 & 0.29 \\
FI $\rightarrow$ NWOM & -0.06 & 0.15 & $-0.27^{*}$ & 0.10 & 1.21 & 0.23 \\
FC $\rightarrow$ NWOM & 0.01 & 0.14 & $-0.33^{*}$ & 0.10 & 2.04 & $<0.05$ \\
$\mathrm{SER} \rightarrow$ NWOM & 0.11 & 0.19 & -0.07 & 0.15 & 0.76 & 0.45 \\
$\mathrm{RER} \rightarrow \mathrm{NWOM}$ & $-0.35^{*}$ & 0.18 & 0.03 & 0.08 & 2.10 & $<0.05$ \\
$\mathrm{SU} \rightarrow$ NWOM & $0.27^{* *}$ & 0.18 & 0.09 & 0.18 & 0.70 & 0.49 \\
$\mathrm{TS} \rightarrow$ NWOM & -0.15 & 0.18 & $0.30^{*}$ & 0.14 & 2.01 & $<0.05$ \\
\hline
\end{tabular}

Note: $\beta$ - Standardized path coefficients, SE - Standard errors. 
